\title{
Demequina lutea sp. nov., isolated from a high Arctic permafrost soil
}

\author{
Kai Waldemar Finster, ${ }^{1}$ Rodney Andrew Herbert, ${ }^{1,2}$ Kasper Urup Kjeldsen, ${ }^{1}$ \\ Peter Schumann ${ }^{3}$ and Bente Aagaard Lomstein ${ }^{1}$
}

Correspondence Kai Waldemar Finster Kai.Finster@biology.au.dk

\author{
${ }^{1}$ Department of Biological Sciences, Section for Microbiology, Building 1540, University of Aarhus, \\ Ny Munkegade, DK-8000 Aarhus-C, Denmark \\ ${ }^{2}$ Division of Molecular and Environmental Microbiology, College of Life Sciences, University of \\ Dundee, Dundee DD1 4HN, Scotland, UK \\ ${ }^{3}$ DSMZ - Deutsche Sammlung von Mikroorganismen und Zellkulturen, Inhoffenstrasse 7b, \\ D-38124 Braunschweig, Germany
}

\begin{abstract}
Two Gram-stain-positive, pigmented, non-motile, non-spore-forming, pleomorphic, rod-shaped bacteria (strains SV $45^{\top}$ and SV47), isolated from a permafrost soil collected from the Adventdalen valley, Spitsbergen, northern Norway, have been characterized taxonomically using a polyphasic approach. Phylogenetic analysis based on 16S rRNA gene sequences revealed that the two permafrost isolates formed a distinct phyletic line within the suborder Micrococcineae of the order Actinomycetales. DNA-DNA hybridization analyses indicate that strains SV45 ${ }^{\top}$ and SV47 are closely related (60-69\% relatedness) and belong to the same species, although they show slightly different colony pigmentation. The closest phylogenetic neighbour was Demequina aestuarii $\mathrm{JC} 2054^{\top}$, with $96 \% 16 \mathrm{~S}$ rRNA gene sequence similarity. Optimum growth of SV45 ${ }^{\top}$ and SV47 occurred aerobically in the absence of $\mathrm{NaCl}$, but both isolates tolerated up to $2 \% \mathrm{NaCl}$ $(w / v)$ in the growth medium. Growth under anaerobic conditions was slow and weak. The peptidoglycan of both isolates was of the $A 4 \beta$ type with L-ornithine as the diamino acid and serine as a component of the interpeptide bridge with either D-aspartate (SV45 ${ }^{\top}$ ) or D-glutamate (SV47) as the $\mathrm{N}$-terminal amino acid. The major fatty acids present in both isolates were $\mathrm{C}_{15: 0}$ $(3.2-8.6 \%)$, iso- $\mathrm{C}_{16: 0}(5.0-8.9 \%)$, anteiso- $\mathrm{C}_{15: 0}(59.4-61.5 \%)$, anteiso- $\mathrm{C}_{17: 0}(4.1-8.8 \%)$ and anteiso- $\mathrm{C}_{15: 1}(4.4-6.4 \%)$. Isoprenoid quinones were present at exceptionally low levels in both isolates, and only demethylmenaquinone DMK- $9\left(\mathrm{H}_{4}\right)$ could be identified with any degree of confidence. Phylogenetic analysis and differences in physiological and biochemical characteristics between the strains and Demequina aestuarii JC2054 ${ }^{\top}$ indicate that these isolates belong to a novel species within the genus Demequina, for which the name Demequina lutea sp. nov. is proposed. The type strain is $\operatorname{SV}_{4} 5^{\top}\left(=\mathrm{LMG}_{24795^{\top}}=\mathrm{DSM} 19970^{\top}\right)$.
\end{abstract}

During the course of a comprehensive study on the bacterial diversity of an Arctic permafrost soil, two closely related non-filamentous actinomycete isolates, designated SV $45^{\mathrm{T}}$ and SV47, were obtained from a soil sample collected in the Adventdalen valley, Spitsbergen $\left(78^{\circ} 12^{\prime}\right.$ $\mathrm{N} 15^{\circ} 50^{\prime} \mathrm{E}$ ), northern Norway, using a standard dilution plating technique (Hansen et al., 2007). Isolation was achieved on R2A agar (Difco) at $15{ }^{\circ} \mathrm{C}$. The isolates were routinely cultured on R2A agar. When large-scale produc-

Abbreviation: DMK, demethylmenaquinone.

The GenBank/EMBL/DDBJ accession number for the 16S rRNA gene sequences of strains SV45 ${ }^{\top}$ and SV47 are EF451745 and EF451735, respectively.

An extended phylogenetic tree based on 16S rRNA gene sequences is available as supplementary material with the online version of this paper. tion of cells was required for chemotaxonomic analyses, cultures were grown in R2A broth (Difco) and incubated at $20{ }^{\circ} \mathrm{C}$ on an orbital shaker at 100 r.p.m. for 5 days before harvesting by centrifugation at $10000 \mathrm{~g}$.

Preliminary sequence comparison with 16S rRNA gene sequences held in the GenBank database indicated that both isolates were phylogenetically related to the suborder Micrococcineae within the order Actinomycetales (Stackebrandt et al., 1997). However, their true taxonomic affiliation was unclear. The present study was carried out to determine whether these isolates represent a novel species and to enable a detailed taxonomic description to be made.

The temperature range for growth was tested on the basis of growth on R2A plates incubated at temperatures ranging from 4 to $40{ }^{\circ} \mathrm{C}$ in increments of about $5{ }^{\circ} \mathrm{C}$. The $\mathrm{pH}$ range 
for growth ( $\mathrm{pH} 5-9$ in increments of $1 \mathrm{pH}$ unit) was determined in $\mathrm{R} 2 \mathrm{~A}$ broth by measuring changes in the $\mathrm{OD}_{600}$ of the cultures over a 10 day incubation period at $25{ }^{\circ} \mathrm{C}$ compared with an uninoculated control. The $\mathrm{pH}$ of the medium was adjusted by the addition of either $1 \mathrm{M}$ $\mathrm{HCl}$ or $1 \mathrm{M} \mathrm{NaOH}$. Salt tolerance was determined by amending $\mathrm{R} 2 \mathrm{~A}$ agar with $\mathrm{NaCl}$ to give final concentrations of $0,1,2,3,4$ and $5 \% \mathrm{NaCl}(\mathrm{w} / \mathrm{v})$. Growth of both isolates occurred at temperatures between 4 and $30{ }^{\circ} \mathrm{C}$, with optimal growth between 25 and $30{ }^{\circ} \mathrm{C}$ at $\mathrm{pH}$ 7. Optimal growth was recorded in the absence of $\mathrm{NaCl}$, but both isolates tolerated up to $2 \% \mathrm{NaCl}(\mathrm{w} / \mathrm{v})$.

Morphological characterization and physiological tests were also performed. Gram staining was carried out according to the method described by Cowan \& Steel (1993). Cell morphology and motility were examined in wet-mount preparations by phase-contrast microscopy using an Olympus $\mathrm{BH} 2$ microscope $(\times 1000$ magnification). The ability of the isolates to grow anaerobically was determined on R2A agar using the Oxoid Anaerobic System. Catalase activity was determined using $3 \% \mathrm{H}_{2} \mathrm{O}_{2}$ $(\mathrm{w} / \mathrm{v})$ and oxidase activity was determined using $1 \%$ tetramethyl $p$-phenylenediamine ( $/ \mathrm{w} / \mathrm{w})$ according to the protocol of Cowan \& Steel (1993). Isolate SV45 ${ }^{\mathrm{T}}$ produces circular, smooth, yellow-pigmented colonies when grown on R2A medium, whereas isolate SV47 produces orangeyellow colonies on the same medium. Both bacteria stain Gram-positive and are catalase-positive, oxidase-negative, non-motile short rods, with cells $0.5-0.7 \mu \mathrm{m}$ wide and $1.5 \mu \mathrm{m}$ long, and do not produce endospores (Table 1).

Biochemical tests including urease activity, nitrate reduction and indole production were determined according to the methods described by Smibert \& Krieg (1994). Additional biochemical tests were performed using API 20NE strips (bioMérieux) and Biolog GN2 plates according to the manufacturers' instructions. Amylase and alkaline phosphatase activity and gelatin hydrolysis were determined according to the methods described by Cowan \&

Table 1. Major morphological, biochemical and chemotaxonomic properties of isolates SV $45^{\top}$ and SV47 properties compared with those of their nearest phylogenetic neighbours

Strains: 1, isolate SV45 ${ }^{\mathrm{T}}$; 2, isolate SV47; 3, Demequina aestuarii JC2054 ${ }^{\mathrm{T}}$; 4, Actinotalea fermentans DSM $3133^{\mathrm{T}}$; 5, Cellulomonas xylanilytica $\mathrm{XIL}_{1}{ }^{\mathrm{T}} ; 6$, Cellulomonas cellasea DSM $20118^{\mathrm{T}}$. All isolates are non-motile and catalase-positive, utilize glucose and xylose and are urease-negative. + , Positive; $(+)$, weakly positive; - , negative; ND, no data available.

\begin{tabular}{|c|c|c|c|c|c|c|}
\hline Characteristic & 1 & 2 & 3 & 4 & 5 & 6 \\
\hline Morphology & Rod & Rod & Rod & Rod & Rod/coccus & Rod \\
\hline Colony colour & Yellow & Orange & Yellow & White & Yellow & Yellow \\
\hline Oxidase & - & - & - & + & + & + \\
\hline Oxygen sensitivity* & FAN & FAN & SA & FAN & FAN & FAN \\
\hline Nitrate reduction & + & + & - & + & + & + \\
\hline Cell-wall peptidoglycan & L-Orn-Ser-D-Asp & L-Orn-Ser-D-Glu & L-Orn-D-Glu & L-Orn-D-Asp & L-Orn-D-Glu & L-Orn-D-Glu \\
\hline Cell-wall sugars $\dagger$ & Glc, Xyl, Rha, Rib & Glc, Xyl, Rha, Rib & ND & Glc, Rha, Rib & Man, Rha, Fuc & Rha, Man, $6 \mathrm{dTa}$ \\
\hline \multicolumn{7}{|l|}{ Utilization of: } \\
\hline Maltose & - & - & + & + & + & + \\
\hline Rhamnose & - & - & - & - & + & - \\
\hline Sucrose & $(+)$ & $(+)$ & + & + & + & + \\
\hline Gluconate & $(+)$ & + & ND & - & ND & - \\
\hline Methyl $\beta$-xyloside & - & - & $\mathrm{ND}$ & + & - & - \\
\hline Lactate & $(+)$ & $(+)$ & $\mathrm{ND}$ & - & - & + \\
\hline Ribose & $(+)$ & + & - & - & $\mathrm{ND}$ & - \\
\hline Dextrin & + & + & $\mathrm{ND}$ & + & - & - \\
\hline \multicolumn{7}{|l|}{ Enzyme activities } \\
\hline Alkaline phosphatase & $(+)$ & - & - & - & ND & + \\
\hline Cellulase & - & - & ND & + & + & + \\
\hline Amylase & - & - & + & ND & + & ND \\
\hline Gelatin hydrolysis & - & - & + & + & $(+)$ & - \\
\hline Major menaquinone & DMK-9 $\left(\mathrm{H}_{4}\right) \ddagger$ & DMK-9 $\left(\mathrm{H}_{4}\right) \ddagger$ & DMK-9 $\left(\mathrm{H}_{4}\right)$ & MK-10 $\left(\mathrm{H}_{4}\right)$ & MK-9 $\left(\mathrm{H}_{4}\right)$ & MK-9 $\left(\mathrm{H}_{4}\right)$ \\
\hline DNA G $+C$ content $(\mathrm{mol} \%)$ & 66.2 & 63.2 & 67.0 & 75.8 & 73.0 & 75.0 \\
\hline References $\S$ & This study & This study & 5 & $1,2,3,5$ & 4 & $1,2,3$ \\
\hline
\end{tabular}

${ }^{*}$ FAN, Facultative anaerobe; SA, strict aerobe.

$\dagger 6 \mathrm{dTal}$, 6-Deoxytalose; Fuc, fucose; Glc, glucose; Man, mannose; Rha, rhamnose; Rib, ribose; Xyl, xylose. Data for strains SV45 ${ }^{\mathrm{T}}$ and SV47 are whole-cell sugars.

¥Trace amount.

\$Sources of data are indicated as follows: 1, An et al. (2005); 2, Bagnara et al. (1985); 3, Jones et al. (2005); 4, Rivas et al. (2004); 5, Yi et al. (2007). 
Table 2. Cellular fatty acid profiles of isolates $S V 45^{\top}$ and SV47 and their closest phylogenetic neighbour, D. aestuarii $\mathrm{JC} 2054^{\top}$

Values are percentages of total fatty acids. Data for D. aestuarii JC2054 ${ }^{\mathrm{T}}$ were taken from Yi et al. (2007).

\begin{tabular}{|c|c|c|c|}
\hline Fatty acid & $\mathrm{SV} 45^{\mathrm{T}}$ & SV47 & $\begin{array}{l}\text { D. aestuarii } \\
\text { JC2054 }^{\mathrm{T}}\end{array}$ \\
\hline \multicolumn{4}{|c|}{ Straight-chain saturated } \\
\hline $\mathrm{C}_{14: 0}$ & 1.79 & 1.52 & 1.59 \\
\hline $\mathrm{C}_{15: 0}$ & 3.22 & 8.58 & 4.16 \\
\hline $\mathrm{C}_{16: 0}$ & 1.39 & 1.19 & 10.40 \\
\hline $\mathrm{C}_{17: 0}$ & 0.14 & 0.18 & 0.70 \\
\hline \multicolumn{4}{|c|}{ Branched saturated } \\
\hline iso- $\mathrm{C}_{14: 0}$ & 2.33 & 2.99 & 1.08 \\
\hline iso- $\mathrm{C}_{15: 0}$ & 3.05 & 0.87 & 3.31 \\
\hline iso- $\mathrm{C}_{16: 0}$ & 8.88 & 4.96 & 6.96 \\
\hline iso- $\mathrm{C}_{17: 0}$ & 0.18 & 0.18 & 0.91 \\
\hline anteiso- $\mathrm{C}_{15: 0}$ & 59.40 & 61.50 & 46.80 \\
\hline anteiso- $\mathrm{C}_{17: 0}$ & 8.84 & 4.11 & 13.10 \\
\hline \multicolumn{4}{|c|}{ Mono-unsaturated } \\
\hline iso- $\mathrm{C}_{15: 1}$ & 0.52 & 0.14 & 0.68 \\
\hline anteiso- $\mathrm{C}_{15: 1}$ & 6.42 & 4.35 & 10.20 \\
\hline
\end{tabular}

Steel (1993). Detailed results from the physiological and biochemical analyses are given in Table 1 and the species description.

The cellular fatty acid composition of the isolates was determined according to the Microbial Identification System (MIDI) protocols. Cellular fatty acid profiles of both isolates together with their closest phylogenetic neighbour (Demequina aestuarii $\mathrm{JC} 2054^{\mathrm{T}}$ ) are presented in Table 2. The data show that the major cellular fatty acids are anteiso- $\mathrm{C}_{15: 0}$, anteiso- $\mathrm{C}_{17: 0}$, iso- $\mathrm{C}_{16: 0}$ and anteiso$\mathrm{C}_{15: 1}$ in both isolates and that the profiles are similar to that of $D$. aestuarii $\mathrm{JC}^{2} 254^{\mathrm{T}}$. Analysis of respiratory quinones was performed by HPLC as described by Groth et al. (1996). Levels of respiratory quinones appear to be exceptionally low in both isolates, and quinones could only be detected at high detector sensitivities, which made identification extremely difficult. The only isoprenoid quinone that could be positively identified, in trace amounts, on the basis of its HPLC retention time was demethylmenaquinone DMK-9 $\left(\mathrm{H}_{4}\right)$. Repeated attempts to produce cell biomass with increased levels of respiratory quinones have so far proved unsuccessful. Peptidoglycan from both isolates was purified and analysed according to the method of Schleifer \& Seidl (1985) and was of the A4 $\beta$ type of cross-linking, with L-ornithine as the diamino acid, serine as a component of the interpeptide bridge and either D-aspartate $\left(\mathrm{SV}_{4} 5^{\mathrm{T}}\right)$ or D-glutamate $(\mathrm{SV} 47)$ as the $\mathrm{N}$ terminal amino acid. Peptidoglycan type A4 $\beta$ is widely distributed amongst members of the genus Cellulomonas (Stackebrandt et al., 2006) as well as D. aestuarii JC2054 ${ }^{\mathrm{T}}$ (Yi et al., 2007). Whole-cell sugar analysis was carried out as described by Staneck \& Roberts (1974).
Bacterial DNA preparation and PCR amplification and sequencing of the $16 \mathrm{~S}$ rRNA gene were performed as described by Hansen et al. (2007). The resultant $16 \mathrm{~S}$ rRNA gene sequences for isolates SV $45^{\mathrm{T}}$ and SV47 were compiled and added to the alignment of the Silva SSURef version 94 database (Pruesse et al., 2007) using the ARB program package (Ludwig et al., 2004). The phylogenetic placement of strains SV45 ${ }^{\mathrm{T}}$ and SV47 within the actinobacterial suborder Micrococcineae was inferred by Bayesian analysis (Ronquist \& Huelsenbeck, 2003) of a dataset composed of 140 taxa with sampling of 1280 sequence positions between Escherichia coli positions 56 and 1365. Tree searches were performed with the general time-reversible evolutionary model with gamma-distributed rate variation across sites, with a proportion of the sites being kept invariable. The searches were carried out with program default priors on model parameters as well as default settings for the Metropolis-coupled Markov chain Monte Carlo runs and included 2500000 generations with a sampling of trees for every 100 . A consensus tree was constructed after removing the first 6250 trees as 'burn-in'. Neighbour-joining (with Jukes-Cantor distance correction)-based bootstrap analysis (100 replications) was performed using PHYLIP version 3.67 (Felsenstein, 2007). On the basis of pairwise 16S rRNA gene sequence comparisons, isolate $\mathrm{SV} 45^{\mathrm{T}}$ showed the highest sequence similarity to D. aestuarii $\mathrm{JC}^{2} 254^{\mathrm{T}}$ (96\%) and Actinotalea fermentans DSM $3133^{\mathrm{T}}$ (94\%). No other taxa exhibited more than a $93 \%$ sequence similarity to our isolates. It is evident from the phylogenetic tree (Fig. 1) that isolates $\mathrm{SV} 45^{\mathrm{T}}$ and $\mathrm{SV} 47$ form a distinct lineage within the suborder Micrococcineae.

The DNA G $+\mathrm{C}$ contents of the two isolates were determined by reversed-phase HPLC (Mesbah et al., 1989) as $66.2 \mathrm{~mol} \%\left(\mathrm{SV}^{2} 5^{\mathrm{T}}\right)$ and $63.2 \mathrm{~mol} \%$ (SV47), similar to that reported by Yi et al. (2007) for D. aestuarii JC2054 ${ }^{\mathrm{T}}$ $(67 \mathrm{~mol} \%)$. In contrast, the DNA $\mathrm{G}+\mathrm{C}$ contents for members of the genus Cellulomonas are higher (71.5$76.0 \mathrm{~mol} \%$; Stackebrandt et al., 2006).

In summary, with the exception of the unusually low levels of the respiratory isoprenoid quinone demethylmenaquinone DMK-9 $\left(\mathrm{H}_{4}\right)$, the morphological, biochemical and chemotaxonomic attributes of isolates $\mathrm{SV} 45^{\mathrm{T}}$ and $\mathrm{SV} 47$ are consistent with the description of members of the genus Demequina. This conclusion is supported by the 16S rRNA gene sequence analysis (Fig. 1). However, differences in a number of biochemical and physiological characteristics, including the lower maximum growth temperature $\left(30{ }^{\circ} \mathrm{C}\right)$, the lower salt tolerance $(2 \% \mathrm{w} / \mathrm{v} \mathrm{NaCl})$, the ability to grow under anaerobic conditions, albeit slowly, the ability to reduce nitrate to nitrite and the presence of alkaline phosphatase activity, distinguish isolates $\mathrm{SV} 45^{\mathrm{T}}$ and SV47 from the only member of this genus with a validly published name, $D$. aestuarii, indicating that they represent a taxonomically distinct species. Therefore, we propose that these isolates should be classified within a novel species of the genus Demequina in the suborder Micrococcineae. 


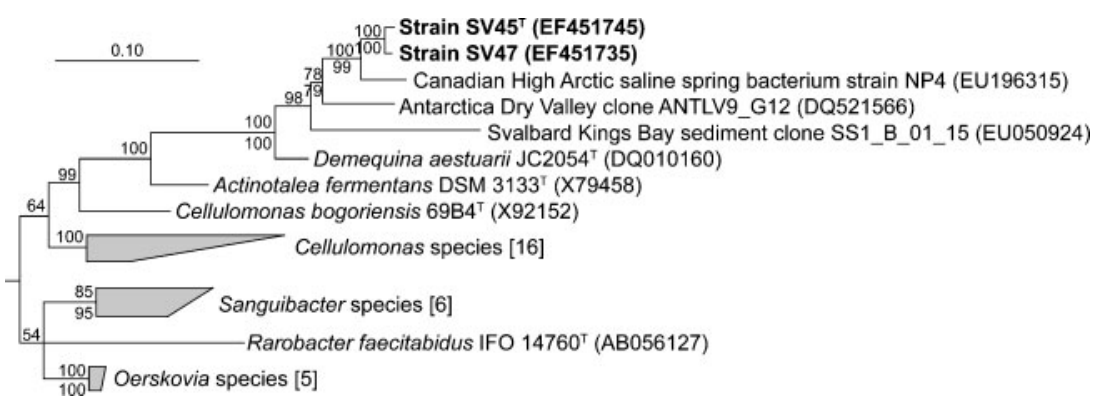

Fig. 1. Phylogenetic position of strains $S V 45^{\top}$ and SV47 among selected taxa affiliated with the actinobacterial suborder Micrococcineae. The tree was inferred from Bayesian analysis of a 16S rRNA gene sequence dataset comprising 140 actinobacterial taxa, several of which were subsequently removed from the presented tree (a complete version is available as Supplementary Fig. S1 in IJSEM Online). Bayesian posterior probability percentages are stated above nodes and neighbour-joiningbased bootstrap percentage values are stated below. Numerals in square brackets indicate the number of taxa constituting the respective groupings. Bar, $10 \%$ estimated sequence divergence.

\section{Description of Demequina lutea sp. nov.}

Demequina lutea (lu'te.a. L. fem. adj. lutea yellow).

Cells stain Gram-positive and are non-motile, non-sporeforming rods $(0.5-0.7 \times 1.5 \mu \mathrm{m})$. Colonies on R2A medium are circular, smooth and yellow-pigmented. Grows optimally under aerobic conditions on R2A medium but also grows slowly under strictly anaerobic conditions. Growth occurs at $4-30{ }^{\circ} \mathrm{C}$ with an optimum between 25 and $30{ }^{\circ} \mathrm{C}$. Extended incubation times are required for cultures grown at $4{ }^{\circ} \mathrm{C}$. The $\mathrm{pH}$ range for growth is 6-9, with an optimum at $\mathrm{pH} 7$. Cells grow optimally in the absence of salt but tolerate up to $2 \% \mathrm{NaCl}(\mathrm{w} / \mathrm{v})$. Cells are negative for oxidase activity and positive for catalase activity. Nitrate reduction to nitrite is positive, $\mathrm{H}_{2} \mathrm{~S}$ is not produced, arginine is not hydrolysed and indole production is negative. Cells are weakly positive for $\beta$-galactosidase and alkaline phosphatase but negative for urease, gelatinase, amylase, cellulase and lipase. Cells can also utilize dextrin, glucose, sucrose and xylose. No growth is observed with acetate, lactate, lactose, maltose, raffinose, rhamnose or ribose. Trace amounts of the respiratory isoprenoid quinone demethylmenaquinone DMK-9 $\left(\mathrm{H}_{4}\right)$ are present. The most abundant fatty acids are $\mathrm{C}_{15: 0}$, iso$C_{16: 0}$, anteiso- $C_{15: 0}$, anteiso- $C_{17: 0}$ and anteiso- $C_{15: 1}$. The peptidoglycan type is A4 $\beta$ based on L-ornithine with a SerD-Asp or Ser-D-Glu interpeptide bridge. The whole-cell sugars are glucose, xylose, rhamnose and ribose. The DNA $\mathrm{G}+\mathrm{C}$ content of the genomic DNA of the type strain is $66.2 \mathrm{~mol} \%$.

The type strain, $\mathrm{SV}_{4} 5^{\mathrm{T}}\left(=\mathrm{LMG} 24795^{\mathrm{T}}=\mathrm{DSM} 19970^{\mathrm{T}}\right)$, was isolated from a permafrost soil sample collected in the Adventdalen valley, Spitsbergen, northern Norway.

\section{Acknowledgements}

We thank Tove Wiegers for expert technical assistance. We are grateful to the Identification Service of the DSMZ for performing the
DNA-DNA hybridization analyses. This study was supported by the Danish Natural Research Council, grant no. 272-06-0576.

\section{References}

An, D.-S., Im, W.-T., Yang, H.-C., Kang, M. S., Kim, K. K., Jin, L., Kim, M. K. \& Lee, S.-T. (2005). Cellulomonas terrae sp. nov., a cellulolytic and xylanolytic bacterium isolated from soil. Int J Syst Evol Microbiol 55, 1705-1709.

Bagnara, C., Toci, R., Gaudin, C. \& Belaich, J. P. (1985). Isolation and characterization of a cellulolytic microorganism, Cellulomonas fermentans sp. nov. Int J Syst Bacteriol 35, 502-507.

Cowan, S. T. \& Steel, K. J. (1993). Manual for the Identification of Medical Bacteria, 3rd edn. Edited by G. I. Barrow \& R. K. A. Feltham. Cambridge: Cambridge University Press.

Felsenstein, J. (2007). PHYLIP (phylogeny inference package) version 3.67. Distributed by the author. Department of Genome Sciences, University of Washington, Seattle, USA.

Groth, I., Schumann, P., Weiss, N., Martin, K. \& Rainey, F. A. (1996). Agrococcus jenensis gen. nov., sp. nov., a new genus of actinomycetes with diaminobutyric acid in the cell wall. Int J Syst Bacteriol 46, 234-239.

Hansen, A. A., Herbert, R. A., Mikkelsen, K., Jensen, L. L., Kristoffersen, T., Tiedje, J. M., Lomstein, B. A. \& Finster, K. W. (2007). Viability, diversity and composition of the bacterial community in a high Arctic permafrost soil from Northern Norway. Environ Microbiol 9, 2870-2884.

Jones, B. E., Grant, W. D., Duckworth, A. W., Schumann, P., Weiss, N. \& Stackebrandt, E. (2005). Cellulomonas bogoriensis sp. nov., an alkaliphilic cellulomonad. Int J Syst Evol Microbiol 55, 1711-1714.

Ludwig, W., Strunk, O., Westram, R., Richter, L., Meier, H., Yadhukumar, Buchner, A., Lai, T., Steppi, S. \& other authors (2004). ARB: a software environment for sequence data. Nucleic Acids Res 32, 1363-1371.

Mesbah, M., Premachandran, U. \& Whitman, W. B. (1989). Precise measurement of the $\mathrm{G}+\mathrm{C}$ content of deoxyribonucleic acid by high-performance liquid chromatography. Int J Syst Bacteriol 39, 159-167.

Pruesse, E., Quast, C., Knittel, K., Fuchs, B., Ludwig, W., Peplies, J., Glöckner, F. \& Silva, O. (2007). A comprehensive online resource for quality checked and aligned ribosomal RNA sequence data compatible with ARB. Nucleic Acids Res 35, 7188-7196. 
Rivas, R., Trujillo, M. E., Mateos, P. F., Martínez-Molina, E. \& Velázquez, E. (2004). Cellulomonas xylanilytica sp. nov., a cellulolytic and xylanolytic bacterium isolated from a decayed elm tree. Int J Syst Evol Microbiol 54, 533-536.

Ronquist, F. \& Huelsenbeck, J. P. (2003). MrBayes 3: Bayesian phylogenetic inference under mixed models. Bioinformatics 19, 1572-1574.

Schleifer, K. H. \& Seidl, P. H. (1985). Chemical composition and structure of murein. In Chemical Methods in Bacterial Systematics, pp. 201-219. Edited by M. Goodfellow \& D. E. Minnikin. London: Academic Press.

Smibert, R. M. \& Krieg, N. R. (1994). Phenotypic characterization. In Methods for General and Molecular Bacteriology, pp. 607-654. Edited by P. Gerhardt, R. G. E. Murray, W. A. Wood \& N. R. Krieg. Washington, DC: American Society for Microbiology.
Stackebrandt, E., Rainey, F. A. \& Ward-Rainey, N. L. (1997). Proposal for a new hierarchic classification system, Actinobacteria classis nov. Int J Syst Bacteriol 47, 479-491.

Stackebrandt, E., Schumann, P. \& Prauser, H. (2006). The family Cellulomonadaceae. In The Prokaryotes: a Handbook on the Biology of Bacteria, 3rd edn, vol. 3, pp. 983-1001. Edited by M. Dworkin, S. Falkow, E. Rosenberg, K. H. Schleifer \& E. Stackebrandt. New York: Springer.

Staneck, J. L. \& Roberts, G. D. (1974). Simplified approach to identification of aerobic actinomycetes by thin-layer chromatography. Appl Microbiol 28, 226-231.

Yi, H., Schumann, P. \& Chun, J. (2007). Demequina aestuarii gen. nov., sp. nov., a novel actinomycete of the suborder Micrococcineae, and reclassification of Cellulomonas fermentans Bagnara et al. 1985 as Actinotalea fermentans gen. nov., comb. nov. Int J Syst Evol Microbiol 57, 151-156. 